\title{
OH in naturally occurring corundum
}

\author{
ANTON BERAN* and GEORGE R. ROSSMAN \\ Division of Geological and Planetary Sciences, California Institute of Technology, \\ Pasadena, CA 91125-2500 USA
}

\begin{abstract}
Hydroxide bands arising from intrinsic hydrous defects have been observed in the infrared spectra of 159 corundum crystals from worldwide localities. The $\mathrm{OH}$ defects are most prominent in blue sapphire crystals, suggesting an association of $\mathrm{OH}$ with redox reactions involving iron. Using a calibration for $\mathrm{OH}$ in kyanite, the absolute concentrations for $\mathrm{OH}$ in corundum are found to be generally 0.5 wt.ppm or lower. The linear $\mathrm{OH}$ absorption coefficient for the most intense band centered at $3310 \mathrm{~cm}^{-1}$ never exceeds $0.5 \mathrm{~cm}^{-1}$. In addition to the intrinsic $\mathrm{OH}$ defects, a number of previously identified hydrous inclusions often contribute to absorptions in the $\mathrm{OH}$ stretching region of the corundum infrared spectrum.
\end{abstract}

Key-words: corundum, $\mathrm{OH}$ defects, nominally anhydrous minerals, infrared spectroscopy.

\section{Introduction}

While it is now established that trace amounts of $\mathrm{OH}$ commonly occur in nominally anhydrous silicate minerals, there have been comparatively few studies of $\mathrm{OH}$ in the common oxide minerals. Significant amounts of $\mathrm{OH}$ can occur in rutile (Hammer \& Beran, 1991; Vlassopoulos et al., 1993; Maldener et al., 2001) and isolated instances of small amounts of $\mathrm{OH}$ have been reported in anatase, brookite, cassiterite (Beran \& Zemann, 1971; Maldener et al., 2001; Libowitzky \& Beran, 2004; Losos \& Beran, 2004), and manganese oxides (Potter \& Rossman, 1979). Recognizing that there have been several reports of $\mathrm{OH}$ in synthetic corundum and occasional reports of $\mathrm{OH}$ in natural corundum, we studied naturally occurring corundum representing different varieties and geographic localities to ascertain if $\mathrm{OH}$ is a common component of this mineral and to determine the actual amount.

Colored varieties of corundum give us two of our most important gemstones: red rubies and sapphires in a variety of different colors. Large, synthetic single-crystals are grown for a variety of technological applications because, among other reasons, of their superior hardness and optical transmission. Consequently, a variety of studies addressed the infrared (IR) transmission of corundum. In synthetic corundum, $\mathrm{OH}$ groups are recognized both as a component of included phases and as a trace component of corundum itself. Belt (1967) described broad absorption bands combined with several narrow bands in the $\mathrm{OH}$ region (3100-3600 $\left.\mathrm{cm}^{-1}\right)$ of the IR spectrum of hydrothermally grown ruby and attributed two sharp bands at 3230 and $3180 \mathrm{~cm}^{-1}$ to the presence of monohydrate phases (boehmite, diaspore). Eigenmann et al. (1972) described $\mathrm{OH}$ bands in Verneuil sapphires at 3310, 3230, 3180 and $3025 \mathrm{~cm}^{-1}$ and Volynets et al. (1972) observed OH absorptions in the spectra of Verneuil-grown corundums with sharp bands at 3420, 3310, 3275, 3225 and $3160 \mathrm{~cm}^{-1}$. Polarized measurements of the sharp bands, now attributed to $\mathrm{OH}$ groups incorporated in the corundum structure, indicated that the $\mathrm{OH}$ groups causing them are aligned perpendicular to the $c$-axis.

A polarized IR-spectroscopic study of a suite of 22 Verneuil-grown corundums (Beran, 1991) found that variously colored samples show a distinct variability in the region of the $\mathrm{OH}$ fundamental vibration. Narrow, strongly polarized $\mathrm{OH}$ bands are centered at 3310, 3230 and $3185 \mathrm{~cm}^{-1}$ and are correlated to cation vacancies. Regarding this band as a triplet, two types of spectra are discernible; the type I spectrum is defined by a strong absorption band at $3230 \mathrm{~cm}^{-1}$ whereas the band at $3310 \mathrm{~cm}^{-1}$ is most prominent in type II spectrum. Additional weak bands at $3290 \mathrm{~cm}^{-1}$ occur in (V, Cr, Fe, Ti)-doped "alexandrite" sapphires, weak bands at 3280 and $3160 \mathrm{~cm}^{-1}$ were observed in colorless and light rose corundum. Moon \& Phillips (1991) described strong $\mathrm{OH}$ bands centered at 3309,3232 and $3187 \mathrm{~cm}^{-1}$, and additional weak bands at

\footnotetext{
* Permanent address: Institut für Mineralogie und Kristallographie, Universität Wien - Geozentrum, Althanstrasse 14, A-1090 Wien, Austria; e-mail: anton.beran@univie.ac.at
} 
3367 and $3295 \mathrm{~cm}^{-1}$. The $\mathrm{OH}$ defects appear to be correlated to vacant $\mathrm{Al}$ sites and to the presence of tetravalent $\mathrm{Ti}$ (Moon \& Phillips, 1994). Two distinct types of OH absorption bands were reported for hydrothermally treated synthetic sapphires by Kronenberg et al. (2000). The first type of bands is characterized by narrow bandwidths and strong polarizations with maximum absorbance measured perpendicular to the $c$-axis. Bands were observed at 3308 , $3293,3278,3231,3208,3183$, and $3163 \mathrm{~cm}^{-1}$. The second type of $\mathrm{OH}$ absorption consists of a broad isotropic band centered at $3400 \mathrm{~cm}^{-1}$, resembling closely the $\mathrm{OH}$ bands of hydrothermally grown quartz (Kronenberg, 1994).

A plausible model of $\mathrm{OH}$ incorporation, based on polarized measurements, was developed under the assumption of an incomplete occupancy of the cation positions. Assuming vacancies $\left(V_{\mathrm{Al}}\right)$ in the Al lattice, in a model developed by Beran (1991), the $\mathrm{OH}$ dipole oriented perpendicular to the $c$-axis is coordinated to two $\mathrm{Al}$ atoms forming groups of face-sharing $\mathrm{Al}_{2}(\mathrm{OH}) \mathrm{O}_{8}$-double octahedra. In this model, the splitting of the triplet band with maxima at 3310,3230 and $3185 \mathrm{~cm}^{-1}$ is mainly controlled by vacancies and not by coloring cations. This model is reenforced by the study of Moon \& Phillips (1991) who investigated the thermal behavior of the $\mathrm{OH}$ triplet band in a series of heating experiments on synthetic corundum and assigned the $\mathrm{OH}$ absorptions to different types of $\left(\mathrm{Ti}_{\mathrm{Al}} V_{\mathrm{Al}} \mathrm{OH}_{\mathrm{O}}\right)$ defect clusters.

There are also suggestions that $\mathrm{OH}$ may occur in natural corundum. Beran (1991) observed extremely weak $\mathrm{OH}$ absorptions at 3310,3230 and $3185 \mathrm{~cm}^{-1}$ in the spectra of a ruby from Sri Lanka and a blue sapphire from Montana. Because the samples used in this study were faceted gemstones, it was not ascertained if these corundums were in their natural state or if they had been subjected to hightemperature heat treatment, likely under reducing conditions. Such treatment is a common practice in the manufacture of the corundum gemstones that can introduce hydroxide in corundum through the reaction,

$$
2 \mathrm{Fe}^{3+}+2 \mathrm{O}^{2-}+\mathrm{H}_{2} \rightarrow 2 \mathrm{Fe}^{2+}+2 \mathrm{OH}^{-} \text {. }
$$

Hydroxide $(\mathrm{OH})$ introduced this way has a spectrum with features at the same wavenumbers. This treatment is commonly applied to sapphires (Emmett et al., 2003). Such concerns are justified in view of the observations of Smith (1995) and Peretti et al. (1995) of comparable sharp OH bands in heat treated ruby, but not in untreated natural samples. Further confirmation of $\mathrm{OH}$ in natural corundum is presented by Smith et al. (1995) who stated that $\mathrm{OH}$ bands are observed in the IR spectra of blue sapphires from basaltic sources in southern Vietnam, and Emmett et al. (2003) who reported $\mathrm{OH}$ bands at 3367, 3310, 3233, and $3185 \mathrm{~cm}^{-1}$ in a pink sapphire from Vietnam. The present study represents an extension of the initial examination of natural corundums with many samples with better controlled histories.

\section{Sample description and experimental methods}

A collection of 159 corundum crystals, summarized in Table 1, was obtained from private collectors and museum collections with the objective of obtaining untreated crystals. Many of these represented old collections believed to have been collected before the practice of heat treating corundum became commonplace. Furthermore, many of these crystals have internal flaws that would render them unsuitable for gemstone purposes, but have sufficient clear regions to be studied with our techniques. To clarify the question of the presence of $\mathrm{OH}$ in naturally occurring corundum, samples from a variety of different localities were studied.

The samples were carefully cleaned in water but most were not ground and polished. Practically all crystals show rounded faces and most of them were elongated parallel to the $c$-axis. Thicknesses were generally in the range from 0.25 to $0.65 \mathrm{~cm}$. The crystals were examined through different areas which varied from 100 to $600 \mu \mathrm{m}$ in diameter. We examined samples ranging from gem quality to turbid or altered. Generally, the morphology of the crystal made it possible to locate the $c$-axis and to use an orientation that placed the $c$-axis normal to the direction of the propagation of the infrared beam, but this was not accomplished with all samples. Unpolarized IR spectra were recorded from 4000 to $2400 \mathrm{~cm}^{-1}$ on a Nicolet 60SX FTIR spectrometer operating at $2 \mathrm{~cm}^{-1}$ resolution. A ceramic SiC light source, and a $\mathrm{LN}_{2}$ cooled MCT detector were used. Background and sample spectra were respectively obtained from 128 scans in air and through the sample crystal. For polarized measurements, a $\mathrm{LiIO}_{3}$ crystal polarizer was used with a Nicolet Magna 860 FTIR spectrometer with other details the same as for the unpolarized measurements. The linear absorption coefficient, $\alpha$ (in $\mathrm{cm}^{-1}$ ), defined by $\alpha=$ $\mathrm{A} / \mathrm{d}$, where $\mathrm{A}$ is the linear absorbance $\left(\log \left[\mathrm{I}_{0} / \mathrm{I}\right]\right)$ of the most intense and significant $\mathrm{OH}$ absorption band at $3310 \mathrm{~cm}^{-1}$ and $\mathrm{d}$ the thickness of the crystal measured in $\mathrm{cm}$, is presented in Table 1 for unpolarized spectra.

\section{Results and discussion}

The presence of significant absorption at $3310 \mathrm{~cm}^{-1}$ in the spectra of approximately one fifth of all studied samples proves that $\mathrm{OH}$ occurs in natural samples (Table 1). When the $3310 \mathrm{~cm}^{-1}$ absorption is strong, additional weak bands at 3233 and $3185 \mathrm{~cm}^{-1}$ are observed that are identical to the type II spectra of the synthetic corundums (light blue to blue sapphire, "amethyst"-colored sapphire) reported by Beran (1991). In the spectra of samples with the greatest intensity, additional weak bands are observed at 3395 and $3367 \mathrm{~cm}^{-1}$.

A significant correlation exists between the color and the OH-band intensities. Blue to dark blue sapphires generally show the highest amount of $\mathrm{OH}$; the $\mathrm{OH}$ content of light blue sapphires is usually significantly lower. This is especially evident in crystals from Laos, showing varying colors from dark blue to bluish-gray. In general, blue corundums are from igneous sources and are the ones that contain the highest $\mathrm{OH}$ concentrations. Smith (1995) also observed the greatest $\mathrm{OH}$ concentrations in blue sapphires from basaltic rocks such as those from Australia. All corundums with the higher absorption coefficients have blue 
Table 1. Localities, color, wavenumber positions and $\mathrm{OH}$ absorption coefficients for corundum.

\begin{tabular}{|c|c|c|c|}
\hline Sample & Locality & $\begin{array}{l}\text { Number of Samples } \\
\text { and Color }\end{array}$ & $\begin{array}{l}\text { Absorption coefficient } \\
\text { per cm at } 3310 \mathrm{~cm}^{-1} \\
\text { (unpolarized) }\end{array}$ \\
\hline LA 1386 & $\begin{array}{l}\text { Yogo Gulch, } \\
\text { Judith Basin Co., } \\
\text { Montana }\end{array}$ & $\begin{array}{l}2 \text { yellowish-grey } \\
1 \text { greenish-grey } \\
1 \text { greyish-yellow } \\
1 \text { greenish-yellow } \\
2 \text { yellowbdl } \\
1 \text { yellow/greenish-blue }\end{array}$ & $\begin{array}{l}\text { bdl a } \\
\text { bdl } \\
0.006 \\
\text { bdl } \\
\text { bdl }\end{array}$ \\
\hline LA 18947 & $\begin{array}{l}\text { Yogo Gulch, } \\
\text { Judith Basin Co., } \\
\text { Montana }\end{array}$ & $\begin{array}{l}1 \text { light greenish-blue } \\
1 \text { blue/greenish-grey }\end{array}$ & $\begin{array}{l}\text { bdl } \\
0.006\end{array}$ \\
\hline LA 16700 & $\begin{array}{l}\text { Yogo Sapphire Mine, } \\
\text { Judith Basin Co., } \\
\text { Montana }\end{array}$ & $\begin{array}{l}2 \text { light blue } \\
3 \text { blue }\end{array}$ & $\begin{array}{l}\text { bdl, } 0.008 \\
\text { bdl }\end{array}$ \\
\hline LA 16699 & $\begin{array}{l}\text { Dry Cottonwood Gulch, } \\
\text { Silver Bow Co., } \\
\text { Montana }\end{array}$ & $\begin{array}{l}1 \text { colorless/yellow } \\
2 \text { light greyish-blue } \\
4 \text { greyish-blue }\end{array}$ & $\begin{array}{l}0.006 \\
\text { bdl, } 0.003 \\
0.01-0.012\end{array}$ \\
\hline LA 18946 & $\begin{array}{l}\text { El Dorado Bar, } \\
\text { Lewis \& Clark Co., } \\
\text { Montana }\end{array}$ & $\begin{array}{l}2 \text { greyish-blue } \\
3 \text { bluish-grey } \\
1 \text { greenish-blue } \\
2 \text { light blue } \\
2 \text { yellow } \\
1 \text { rose }\end{array}$ & $\begin{array}{l}0.01-0.016 \\
\text { bdl } \\
0.01 \\
0.01 \\
\text { bdl } \\
\text { bdl }\end{array}$ \\
\hline GRR 849 & $\begin{array}{l}\text { Rock Creek, } \\
\text { Montana }\end{array}$ & $\begin{array}{l}2 \text { colorless } \\
2 \text { light blue } \\
1 \text { greenish-blue } \\
2 \text { light yellow } \\
2 \text { rose }\end{array}$ & $\begin{array}{l}\text { bdl } \\
\text { bdl } \\
0.007 \\
\text { bdl } \\
\text { bdl }\end{array}$ \\
\hline GRR 675 & $\begin{array}{l}\text { Near Coal Creek, } \\
\text { Montana }\end{array}$ & $\begin{array}{l}1 \text { colorless } \\
1 \text { yellow }\end{array}$ & $\begin{array}{l}\text { bdl } \\
\text { bdl }\end{array}$ \\
\hline GRR 836 & Montana & $\begin{array}{l}5 \text { light blue } \\
1 \text { light greyish-blue } \\
3 \text { light greenish-blue }\end{array}$ & $\begin{array}{l}\text { bdl } \\
\text { bdl } \\
\text { bdl }-0.05\end{array}$ \\
\hline LA 12229 & $\begin{array}{l}\text { Macon Co., } \\
\text { North Carolina }\end{array}$ & $\begin{array}{l}1 \text { dark blue } \\
1 \text { dark blue }\end{array}$ & $\begin{array}{l}0.12 \\
0.16\end{array}$ \\
\hline LA 12230 & $\begin{array}{l}\text { Macon Co., } \\
\text { North Carolina }\end{array}$ & $\begin{array}{l}2 \text { greenish-grey } \\
1 \text { bluish-grey } \\
1 \text { greenish-blue }\end{array}$ & $\begin{array}{l}\text { bdl } \\
0.085 \\
\text { bdl }\end{array}$ \\
\hline GRR 1054 & Queensland, Australia & 4 greenish-blue & $0.03-0.17$ \\
\hline GRR 1020 & Australia(?) & $\begin{array}{l}1 \text { blue } \\
2 \text { dark blue }\end{array}$ & $\begin{array}{l}0.15 \\
0.1,0.16^{b}\end{array}$ \\
\hline GRR 1047 & Australia & 1 blue & 0.17 \\
\hline LA 6908 & Australia & $\begin{array}{l}1 \text { bluish-grey/yellow } \\
1 \text { greenish-blue/yellow } \\
1 \text { blue }\end{array}$ & $\begin{array}{l}\text { bdl } \\
0.01 \\
0.49\end{array}$ \\
\hline GRR 1334 & Malacheta, Brazil & 1 blue (faceted) & 0.33 \\
\hline GRR 1335 & Goiaz, Brazil & 1 light blue (faceted) & 0.24 \\
\hline GRR 1021 & Cambodia & 1 brown/yellow & bdl \\
\hline GRR 1065 & Greenland & 2 red & bdl \\
\hline GRR 2236 & Shandong, China & 1 dark blue & 0.184 \\
\hline GRR 906 & Kenya & $\begin{array}{l}1 \text { violet } \\
1 \text { rose } \\
2 \text { red }\end{array}$ & $\begin{array}{l}0.06 \\
\text { bdl } \\
\text { bdl }\end{array}$ \\
\hline GRR 1870 & Ban Houayxay, Laos & $\begin{array}{l}4 \text { greenish-blue } \\
1 \text { bluish-grey } \\
3 \text { blue } \\
1 \text { dark blue } \\
1 \text { green } \\
1 \text { brownish-green } \\
1 \text { brownish-yellow } \\
\text { (zoned crystals) }\end{array}$ & $\begin{array}{l}\text { bdl }-0.025 \\
0.01 \\
0.01-0.023 \\
0.15 \\
\text { bdl } \\
\text { bdl } \\
0.01\end{array}$ \\
\hline GRR 788 & Nigeria & $\begin{array}{l}1 \text { dark blue/light blue } \\
\text { (zoned) }\end{array}$ & 0.14 \\
\hline
\end{tabular}


Table 1. continued.

\begin{tabular}{|c|c|c|c|}
\hline Sample & Locality & $\begin{array}{l}\text { Number of Samples } \\
\text { and Color }\end{array}$ & $\begin{array}{l}\text { Absorption coefficient } \\
\text { per } \mathrm{cm} \text { at } 3310 \mathrm{~cm}^{-1} \\
\text { (unpolarized) }\end{array}$ \\
\hline GRR 662 & SE Asia & $\begin{array}{l}1 \text { colorless } \\
2 \text { greyish-blue }\end{array}$ & $\begin{array}{l}\text { bdl } \\
0.01,0.10\end{array}$ \\
\hline GRR 1382 & SE Asia & 1 colorless & bdl \\
\hline GRR 1045 & Ratnapura, Sri Lanka & 1 colorless & bdl \\
\hline GRR 2239 & Rwanda & 1 dark blue & 0.009 \\
\hline GRR 540 & Sri Lanka & 1 rose & 0.003 \\
\hline GRR 673 & Sri Lanka & 3 yellow & bdl \\
\hline \multirow[t]{3}{*}{ GRR 674} & Sri Lanka & 1 colorless/yellow & bdl \\
\hline & & 1 bluish-grey/yellow & bdl \\
\hline & & 1 light grey/red & bdl \\
\hline \multirow[t]{3}{*}{ LA 19734} & Sri Lanka & 3 colorless & bdl \\
\hline & & 1 colorless/yellow & bdl \\
\hline & & 1 light blue & 0.006 \\
\hline \multirow[t]{3}{*}{ LA 19750} & Sri Lanka & 3 colorless & bdl \\
\hline & & 2 greyish-blue & bdl, 0.01 \\
\hline & & 2 yellow & bdl \\
\hline \multirow[t]{3}{*}{ LA 6906} & Sri Lanka & 3 colorless/yellow & bdl \\
\hline & & 1 light yellow & bdl \\
\hline & & 1 grey & bdl \\
\hline \multirow[t]{6}{*}{ GRR 890} & Umba Valley, Tanzania & 2 violet & bdl, 0.015 \\
\hline & & 1 light blue & 0.015 \\
\hline & & 1 blue & 0.028 \\
\hline & & 1 bluish-green & bdl \\
\hline & & 1 yellow & bdl \\
\hline & & 1 red & bdl \\
\hline \multirow[t]{5}{*}{ GRR 730} & Tanzania & 1 violet & 0.015 \\
\hline & & 1 blue & 0.025 \\
\hline & & 1 yellow & bdl \\
\hline & & 1 rose & 0.01 \\
\hline & & 2 red & bdl, 0.025 \\
\hline \multirow[t]{7}{*}{ GRR 838} & Tanzania & 1 colorless & bdl \\
\hline & & 2 light violet & 0.015 \\
\hline & & 1 violet & 0.015 \\
\hline & & 2 violet/grey & $0.02,0.03$ \\
\hline & & 1 light violet/yellow & 0.015 \\
\hline & & 2 yellow/light blue & $0.02,0.027$ \\
\hline & & 1 yellow & 0.03 \\
\hline \multirow[t]{3}{*}{ GRR 736} & Chantaburi, Thailand & 1 bluish-grey & bdl \\
\hline & & 1 blue & 0.048 \\
\hline & & $1 \mathrm{red}$ & bdl \\
\hline
\end{tabular}

The absorption coefficient $\alpha$ is defined by the absorbance, $\mathrm{A}=\log \left[\mathrm{I}_{0} / \mathrm{I}\right]$, divided by the thickness of the crystal, $\mathrm{d}$, measured in cm $(\alpha=$ $\mathrm{A} / \mathrm{d})$.

a bdl means at or below detection limit of about 0.002 .

b GRR 1020; absorption coefficient per $\mathrm{cm}$ at $3310 \mathrm{~cm}^{-1}$ (polarized $\left.\mathrm{E} \perp \mathrm{c}\right)=0.42-0.71$.

hues (Table 1). The highest absorption coefficient value of $0.49 \mathrm{~cm}^{-1}$ was observed for a blue Australian sapphire and blue, faceted sapphires (that may have been heat-treated). Also some greenish-blue and violet sapphires show relatively strong absorption bands. Only one ruby sample yielded a very weak absorption at $3310 \mathrm{~cm}^{-1}$.

Of the large number of samples from Montana mines (Brownlow \& Komorowski, 1988; Mychaluk, 1995), most sapphires from Dry Cottonwood Gulch show significant absorptions due to $\mathrm{OH}$. Sapphires from the gemstone mines in Australia (Guo et al., 1995) reveal the most intense absorption bands. Sapphires from Sri Lanka show very limited amounts of $\mathrm{OH}$, and sapphires from Laos are characterized by $\mathrm{OH}$ zoning. Absorption coefficients of sapphires relatively rich in $\mathrm{OH}$ are concentrated at around $0.15 \mathrm{~cm}^{-1}$.

Sapphires from Montana have been commercially heattreated in a reducing atmosphere since the 1970's (Emmett \& Douthit, 1993) with the consequent introduction of $\mathrm{OH}$ in the process (Emmett et al., 2003). Comparison of the $\mathrm{OH}$ content of our suite of Montana samples to published results of heat-treated material makes it evident that the absorption bands of heat-treated dark blue sapphires are more intense than the bands of the corresponding untreated material. This supports previous suggestions that hydrogen enters mineral structures in a redox reaction, given by 
equation (1), in which $\mathrm{Fe}^{3+}$ is reduced by hydrogen producing an $\mathrm{OH}$ group in its immediate vicinity (Skogby \& Rossman, 1989; Redhammer et al., 1993).

\section{Amount of $\mathrm{OH}$}

Measurements with polarized radiation on natural crystals confirm that the orientation of the $\mathrm{OH}$ dipole is perpendicular to [0001] as previously determined on synthetic material (Eigenmann et al., 1972; Volynets et al., 1972; Beran, 1991; Moon \& Phillips, 1991). All OH bands show maximum absorptions when the electric vector of the polarized radiation vibrates perpendicular to the $c$-axis (Fig. 1). The absolute amount of $\mathrm{OH}$ can be determined from the total integrated areas of the $\mathrm{OH}$ bands by using the expression

$\mathrm{Abs}_{\text {tot }}=\mathrm{I} \times \mathrm{d} \times$ concentration

where $\mathrm{Abs}_{\text {tot }}$ is the total integrated intensity of the $\mathrm{OH}$ bands (as discussed in Bell et al., 2003); $\mathrm{d}$ is the thickness in $\mathrm{cm}$, concentration is in moles $\mathrm{H}_{2} \mathrm{O} /$ liter and $\mathrm{I}$ is the experimentally determined integral molar absorption coefficient. Note that the concentration of all hydrous species is reported as $\mathrm{H}_{2} \mathrm{O}$.

The hydrogen concentration can only be accurately determined if the matrix specific integral molar absorption coefficient, I in equation (2), is known. By comparing the $\mathrm{OH}$ absorbance intensity of the natural sapphires with those of synthetic samples reported by Beran (1991), it is evident that the $\mathrm{OH}$ content of most of the natural material is in the same order of magnitude as most of the synthetic samples. The absolute amount of $\mathrm{OH}$ absorption in the IR spectrum is so low that it appears that an absolute measurement of the $\mathrm{OH}$ in corundum will not be possible with current absolute calibration methods at our disposal. Instead, we must indirectly determine the $\mathrm{OH}$ content through calibration of the $\mathrm{OH}$ band intensity with other standards which we will assume will reasonably represent the behavior of $\mathrm{OH}$ in corundum.

Engstrom et al. (1980) reported an approximate estimate for the $\mathrm{OH}$ content of a synthetic corundum based on the oscillator strength for the $\mathrm{OH}$ ion in $\mathrm{TiO}_{2}$ from Johnson et al. (1973). The result was in the 0.1 wt.ppm range. Beran (1991) subsequently proposed a calibration of the $\mathrm{OH}$ content of sapphire using kyanite with small hydrogen contents, determined by conductometry, as a standard mineral (Beran \& Götzinger, 1987). More similar to corundum than $\mathrm{TiO}_{2}$, kyanite is an aluminosilicate whose structure contains oxygen atoms arranged in a slightly distorted close-packed cubic array and whose IR spectrum shows comparatively sharp $\mathrm{OH}$ absorptions at around 3385 and $3270 \mathrm{~cm}^{-1}$ centered in an energy region similar to that observed in corundum (Wieczorek et al., 2004). The hydrogen concentrations thus calculated using the Beran \& Götzinger (1991) kyanite standard for the synthetic sapphires varied from around 10 to 30 wt.ppm (expressed as $\mathrm{H}_{2} \mathrm{O}$ ).

Subsequently, the accuracy of the kyanite calibration of Beran (1991) was questioned by Bell et al. (2004) who reanalyzed kyanite by nuclear reaction analysis (NRA) and

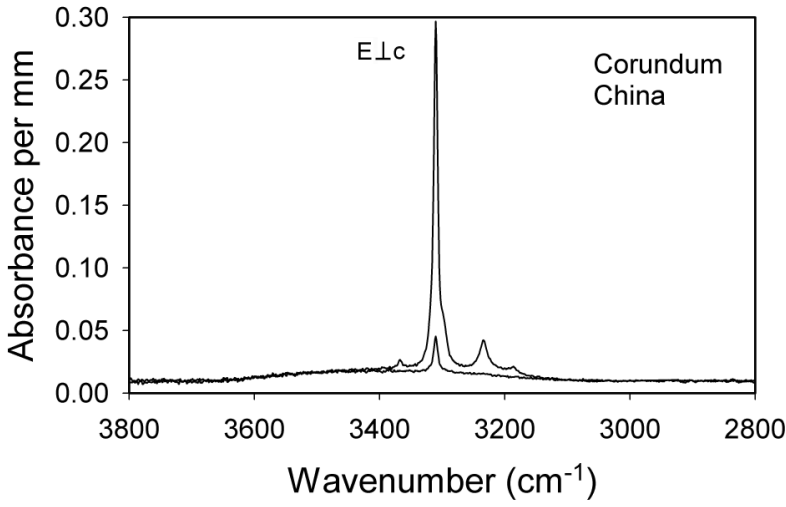

Fig. 1. Polarized single-crystal spectra in the frequency range of the $\mathrm{OH}$ stretching vibrations of a $0.973 \mathrm{~mm}$ thick, blue sapphire, GRR 2236, from Shandong Province, China (Guo et al., 1992), plotted as $1.0 \mathrm{~mm}$ thick, with the electric vector of the polarized radiation vibrating perpendicular and parallel to the $c$-axis. This spectrum is representative of the sharp $\mathrm{OH}$ bands in all natural corundums, but of greater intensity than most. Underlying the sharp $\mathrm{OH}$ bands is a broad, unpolarized band centered near $3420 \mathrm{~cm}^{-1}$ characteristic of liquid water and found in the spectra of many samples.

obtained a different calibration constant which indicated that the earlier work overestimated the $\mathrm{OH}$ content in kyanite by a factor of about 18 . The integral molar absorption coefficient, I, derived by Bell et al. (2004) for kyanite is $\mathrm{I}=32900 \mathrm{~L} \times \mathrm{mol}^{-1} \times \mathrm{cm}^{-2}$. This is between the corresponding values for olivine $(I=28450)$ and clinopyroxene $(\mathrm{I}=38300)$ (Bell et al., 2003, 1995).

The most $\mathrm{OH}$-rich corundum in Table 1 that is not likely to have been artificially heat-treated is sample GRR 2236 from the Shandong Province, China. From Fig. 1, the $\mathrm{Abs}_{\text {tot }}$ (defined as $\mathrm{Abs}_{\| \mathrm{c}}+2 \times \mathrm{Abs}_{\perp \mathrm{c}}$ ) is 72.90 . The weak broad band centered near $3420 \mathrm{~cm}^{-1}$ that underlies the sharp $\mathrm{OH}$ bands was removed through a baseline correction before integration. The amount of $\mathrm{H}_{2} \mathrm{O}$ bound in the corundum is determined from the concentration, $72.90 / 32900=$ 0.00222 moles $\mathrm{H}_{2} \mathrm{O}$ per liter $(4000 \mathrm{~g})$ of corundum. That corresponds to $0.00222 \times 18=0.0399$ grams $\mathrm{H}_{2} \mathrm{O}$ per 4000 grams corundum, which corresponds to $10 \mathrm{wt} . \mathrm{ppm}$. This is the highest observed hydrogen concentration in our natural (not heat-treated) corundum crystals. For most crystals values are 0.5 wt.ppm $\mathrm{H}_{2} \mathrm{O}$ or less. These values exclude the contribution of hydrous components that are present as inclusions of hydrous phases.

Approximations such as proposed by Paterson (1982) and modified by Libowitzky \& Rossman (1997) provide an alternative way to estimate the integral molar absorption coefficients based on the energy of the absorption. For example, Paterson's (1982) relationship was used by Kronenberg et al. (2000) for the evaluation of the $\mathrm{OH}$ defect concentration in their hydrothermally treated corundums. The revised calibration of Libowitzky \& Rossman (1997) leads to an estimate of the $\mathrm{H}_{2} \mathrm{O}$ in corundum GRR 2236 of about 3 wt.ppm $\mathrm{H}_{2} \mathrm{O}$ using the $\mathrm{Abs}_{\text {tot }}$ derived in the previous paragraph. While this is only an estimate of the amount of $\mathrm{OH}$ in corundum, it does serve to confirm the sub-ppm concentrations of $\mathrm{OH}$ we generally find in this 


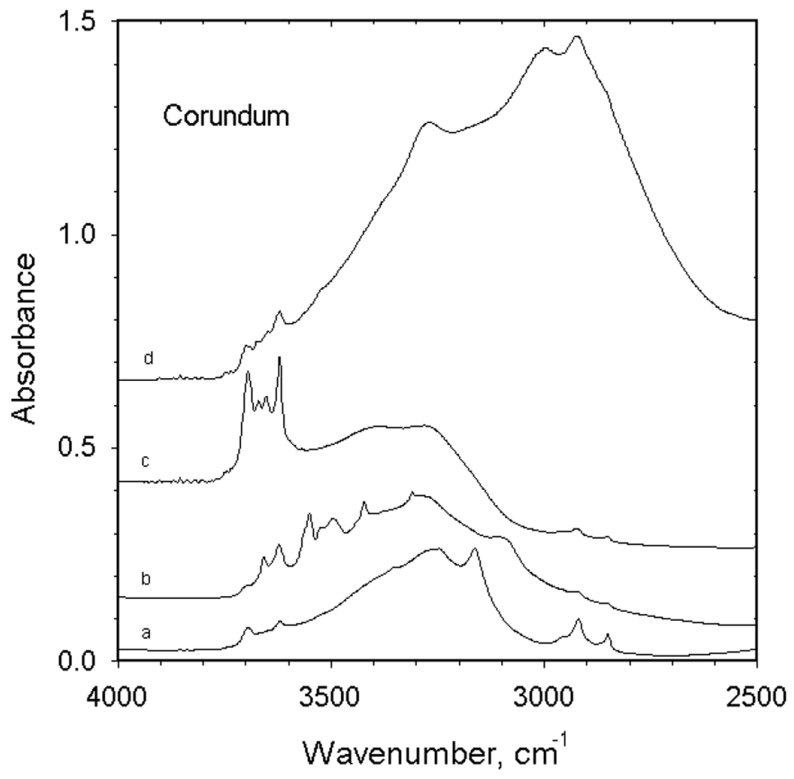

Fig. 2. Unpolarized spectra of corundum in the $\mathrm{OH}$ stretching region, taken through turbid crystal parts. (a) $\mathrm{OH}$ absorption features of goethite - GRR 673, (b) chlorite group minerals - GRR 838, (c) kaolinite group minerals - LA 16699, and (d) diaspore (plus weak kaolilite features) - GRR 730. Weak C-H stretching vibrations occur in the $2850-2950 \mathrm{~cm}^{-1}$ region.

phase. It is interesting to note that the I values obtained on the basis of the NRA kyanite calibration are lower, by a factor of about three, than the values obtained from the IR calibration trend given by Libowitzky \& Rossman (1997) and that a similar factor was reported by Maldener et al. (2001) for rutile and cassiterite, for olivine in Bell et al. (2003) and for pyrope in Libowitzky \& Rossman (1997). The origin of the large differences between the kyanite calibration of Beran \& Götzinger (1987) and the one by Bell et al. (2004) may be explained by the nature of the samples analyzed. The 1987 conductometric analysis required 300 $\mathrm{mg}$ of extremely pure kyanite. In retrospect, it is highly probable that the high hydrogen content that resulted in the calculation of a low I value was due to the presence of then undetected, submicroscopic inclusions of hydrous alteration products and strongly absorbed water located in incipient cleavages on fractured ends of grains.

As an alternative to using the total integrated intensities, it is possible to estimate the concentration of $\mathrm{H}_{2} \mathrm{O}$ from the intensity of the $3310 \mathrm{~cm}^{-1} \mathrm{OH}$ absorption bands (A). This is related to the concentration of the $\mathrm{OH}$ groups (c) by the molar absorption coefficient $(\varepsilon)$ and the thickness of the samples (d). This relation is expressed by Beer's law

$$
\mathrm{A}=\varepsilon_{\perp \mathrm{c}} \times \mathrm{d} \times \mathrm{c}
$$

where $\varepsilon_{\perp c}$ is determined to be 1077 from the $\mathbf{E} \perp c$ spectrum of Fig. 1 (sample GRR 2236 from China). Because the spectrum of $\mathrm{OH}$ in corundum is generally similar from sample to sample, and because the intensity is primarily in the $\mathbf{E} \perp c$ direction, the $\mathrm{OH}$ content can be estimated from a single spectrum obtained in the $\mathbf{E} \perp c$ direction using the kyanite calibration discussed above. The calibration derived above could be used as the basis for a less accurate calibration based on an unpolarized spectrum taken on a (0001) slab of corundum.

The calibration for unpolarized spectra taken on slabs cut parallel to the $c$-axis is different from that obtained with polarized spectra. In this case, $\varepsilon_{\text {unpol }}$, obtained from the unpolarized spectrum of sample GRR 1020 (corundum from Australia), is 247. Use of $\varepsilon_{\text {unpol }}$ should be considered less accurate because of partial polarization effects in most IR spectrophotometers, even when used without polarizers. In the case of our instrument, rotating the sample 90 degrees about the axis of the light path resulted in a $30 \%$ reduction in the absorbance of the $3310 \mathrm{~cm}^{-1}$ band in the unpolarized spectrum. Also noteworthy is the fact that the intensity of an unpolarized spectrum from a sample can vary by a factor of four depending on its crystallographic orientation.

\section{Hydrous mineral inclusions}

All of the calibrations above do not include hydrous inclusions, yet such inclusions are abundant in many samples of corundum. Guo et al. (1995), Smith (1995) and references therein describe mineral inclusions in gemquality sapphires mainly from Australian and Asian occurrences. Inclusions of hydrous minerals frequently occur in corundum and contribute to its IR spectrum. We observed the spectroscopic features of many of the hydrous minerals reported by Smith (1995) in gem rubies. Features of kaolinite, chlorite, diaspore, boehmite and goethite are the ones we most commonly encountered. We find no correlation between the intensity of the $\mathrm{OH}$ absorptions and the optical clarity of the crystals. Spectra taken through turbid portions of crystals show distinct groups of absorption bands centered at different wavenumbers within the $\mathrm{OH}$ fundamental region. Typical examples are shown in Fig. 2. The significant absorption peak of spectrum a) is due to the presence of fine-grained goethite dispersed along fracture surfaces in the crystal which causes the yellow color of a corundum sample from Sri Lanka. The absorptions of chlorite group minerals are frequently observed in sapphires from Montana and Tanzania (Fig. 2 b). The characteristic absorptions of diaspore with a maximum centered at around $2900 \mathrm{~cm}^{-1}$ indicate the source of turbidity in rubies from Tanzania (Fig. 2 d). The most common phases identified from the spectrum of turbid parts of corundum crystals are kaolinite group minerals (Fig. 2c) which show how IR spectroscopy is a very useful method for the identification and characterization of very small amounts of extremely fine-grained contaminating mineral phases.

Acknowledgements: We wish to thank the following people for kindly providing corundum samples for this study: Joe Borden, John Emmett, E. Buzz Gray, Michael Gray, George Harlow, Tony Kampf, Robert E Kane, Peter Keller, H. F. Kennedy, Elbert King, Julius Petch, Robert Weiser and Ray Weldon. This investigation was supported by the Austrian Fonds zur Förderung der wissenschaftlichen Forschung P8122-GEO and the 
National Science Foundation (USA) grants EAR-9218980 and EAR-0125767. Constructive reviews were provided by John Emmett, Christopher Smith, and two anonymous referees.

\section{References}

Bell, D.R., Ihinger, P.D., Rossman, G.R. (1995): Quantitative analysis of hydroxyl in garnet and pyroxene. Am. Mineral., 80, 465-474.

Bell, D.R., Rossman, G.R., Maldener, J., Endisch, D., Rauch, F. (2003): Hydroxide in olivine: A quantitative determination of the absolute amount and calibration of the IR spectrum. $J$. Geophys. Res., 108(B2), 2105-2113.

Bell, D.R., Rossman, G.R., Maldener, J., Endisch, E., Rauch, F. (2004): Hydroxide in kyanite: A quantitative determination of the absolute amount and calibration of the IR spectrum. Mineral., 89, 998-1003.

Belt, F.R. (1967): Hydrothermal ruby: Infrared spectra and X-ray topography. J. Appl. Phys., 38, 2688-2689.

Beran, A. (1991): Trace hydrogen in Verneuil-grown corundum and its colour varieties - an IR pectroscopic study. Eur. J. Mineral., 3, 971-975.

Beran, A. \& Götzinger, M.A. (1987): The quantitative IR spectroscopic determination of structural $\mathrm{OH}$ groups in kyanites. Mineral. Petrol., 36, 41-49.

Beran, A. \& Zemann, J. (1971): Messung des UltrarotPleochroismus von Mineralen. XI. Der Pleochroismus der OHStreckfrequenz in Rutil, Anatas, Brookit und Cassiterit. Tschermaks Mineral. Petrogr. Mitt., 15, 71-80.

Brownlow, A.H. \& Komorowski, J.-C. (1988): Geology and origin of the Yogo sapphire deposit, Montana. Econ. Geol., 83, 875-880.

Eigenmann, K., Kurtz, K., Günthard, H.H. (1972): Solid state reactions and defects in doped Verneuil sapphire. Helvet. Physica Acta, 45, 452-480.

Emmett, J.L. \& Douthit, T.R. (1993): Heat treating the sapphires of Rock Creek, Montana. Gems Gemology, 29, 250-272.

Emmett, J.L., Scarrratt, K., McClure, S.F., Moses, T., Douthit, T.R., Hughes, R., Novak, S., Shigley, J.E., Wang, W., Bordelon, O., Kan, R.E. (2003): Beryllium diffusion of ruby and sapphire. Gems Gemology, 39, 84-135.

Engstrom, H., Bates, J.B., Wang, J.C., Abraham, M.M. (1980): Infrared spectra of hydrogen isotopes in $\alpha-\mathrm{Al}_{2} \mathrm{O}_{3}$. Phys. Rev. B, 21, 1520-1526.

Guo, J., Wang F., Yakoumelos, G. (1992): Sapphires from Changle in Shandong Province, China. Gems Gemology, 28, 255-260.

Guo, J., O'Reilly, S.Y., Griffin, W.L. (1995): Corundum from basaltic terrains: a mineral inclusion approach to the enigma. Contrib. Mineral. Petrol., 122, 368-386.

Hammer, V.M.F. \& Beran, A. (1991): Variations in the OH concentrations of rutiles from different geological environments. Mineral. Petrol., 45, 1-9.

Johnson, O.W., DeFord, J., Shaner, J.W. (1973): Experimental technique for the precise determination of hydrogen and deuterium concentration in rutile. J. Appl. Phys., 44, 3008-3012.

Kronenberg, A.K. (1994): Hydrogen speciation and chemical weakening of quartz. in "Silica", P.J. Heaney et al., eds. Rev. Mineral., 29, 123-176.
Kronenberg, A.K., Castaing, J., Mitchell, T.E., Kirby, S.H. (2000): Hydrogen defects in $\alpha-\mathrm{Al}_{2} \mathrm{O}_{3}$ and water weakening of sapphire and alumina ceramics between 600 and $1000^{\circ} \mathrm{C}$ - I. Infrared characterization of defects. Acta Mater., 48, 1481-1494.

Libowitzky, E. \& Beran, A. (2004): IR spectroscopic characterization of hydrous species in minerals. in "Spectroscopic methods in mineralogy", A. Beran \& E. Libowitzky, eds. EMU Notes Mineral., 6, 227-279.

Libowitzky, E. \& Rossman, G.R. (1997): An IR absorption calibration for water in minerals. Am. Mineral., 82, 1111-1115.

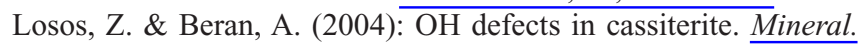
Petrol., 81, 219-234.

Maldener, J., Rauch, F., Gavranic, M., Beran, A. (2001): OH absorption coefficients of rutile and cassiterite deduced from nuclear reaction analysis and FTIR spectroscopy. Mineral. Petrol., 71, 21-29.

Moon, A.R. \& Phillips, M.R. (1991): Defect clustering in H,Ti: $\alpha-$ $\mathrm{Al}_{2} \mathrm{O}_{3}$. J. Phys. Chem. Solids., 52, 1087-1099.

Moon, A.R. \& Phillips, M.R. (1994): Defect clustering and color in Fe,Ti: $\alpha-\mathrm{Al}_{2} \mathrm{O}_{3}$. J. Amer. Ceram. Soc., 77, 356-367.

Mychaluk, K.A. (1995): The Yogo sapphire deposit. Gems Gemology, 31, 28-41.

Paterson, M.S. (1982): The determination of hydroxyl by infrared absorption in quartz, silicate glasses and similar materials. Bull. Minéral., 105, 20-29.

Peretti, A., Schmetzer, K., Bernhardt, H.-J., Mouawad, F. (1995): Rubies from Mong Hsu. Gems Gemology, 31, 2-26.

Potter, R.M. \& Rossman, G.R. (1979): The tetravalent manganese oxides: identification, hydration, and structural relationships by infrared spectroscopy. Am. Mineral., 64, 1199-1218.

Redhammer, G.J., Beran, A., Dachs, E., Amthauer, G. (1993): A Mössbauer and X-ray diffraction study of annites synthesized at different oxygen fugacities and crystal chemical implications. Phys. Chem. Minerals, 20, 382-394.

Skogby, H. \& Rossman, G.R. (1989): OH in pyroxenes: An experimental study of incorporation mechanisms and stability. Am. Mineral., 74, 1059-1069.

Smith, C.P. (1995): A contribution to understanding the infrared spectra of rubies from Mong Hsu, Myanmar. J. Gemmology, 24, 321-335.

Smith, C.P., Kammerling, R.C., Keller, A.S., Peretti, A., Scarratt, K.V., Khoa, N.D., Repetto, S. (1995): Sapphires from southern Vietnam. Gems Gemology, 31, 168-186.

Vlassopoulos, D., Rossman, G.R., Haggerty, S.E. (1993): Coupled substitution of $\mathrm{H}$ and minor elements in rutile and the implications of high $\mathrm{OH}$ contents in $\mathrm{Nb}$ - and $\mathrm{Cr}$-rich rutile from the upper mantle. Am. Mineral., 78, 1181-1191.

Volynets, F.K., Sidorova, Y.A., Stsepuro, N.A. (1972): OH-groups in corundum crystals grown by the Verneuil technique (in Russian). J. Appl. Spectr., 17, 1088-1091.

Wieczorek, A., Libowitzky, E., Beran, A. (2004): A model for the $\mathrm{OH}$ defect incorporation in kyanite based on polarized IR spectroscopic investigations. Schweiz. Mineral. Petrogr. Mitt., 84, 333-343.

Received 26 January 2006

Accepted 27 March 2006 